\title{
PENGAPLIKASIAN POLA COMPUTER MEDIATED COMMUNICATION (CMC) DALAM DAKWAH
}

\author{
Oleh: Sri Hadijah Arnus \\ Dosen Fakultas Ushuluddin, Adab dan Dakwah \\ IAIN Kendari \\ Email :hadijaharnus@gmail.com
}

\begin{abstract}
Abstrak
Penelitian ini berbicara komunikasi yang menggunakan komputer sebagai perantara (medium). Hal ini berkembang seiring kemajuan teknologi komunikasi dan internet. Medium ini dikenal dengan nama Computer Mediated Communication (CMC). Hal yang berkaitan dengan ini seperti sistem obrolan, website dalam bentuk world wide web. Di dalamnya mencakup sistem tekstual. Grafis, fotografi, audio, dan video yang keseluruhan menggunakan aspek hyperlink. penulis menganggap bahwa penerapan pola CMC ini sebagai pelengkap dan memperkaya metode dakwah yang telah ada sekarang ini. Metode dakwah yang dilakukan secara face to face hendaknya tidak dihilangkan dan akan terus dikembangan sehngga tidak kalah dengan kemajuan teknologi saat ini.
\end{abstract}

\section{Kata Kunci Computer Mediated Communication (CMC), Komunikasi}

\section{Pendahuluan}

Perkembangan komunikasi sampai pada saat ini tentulah mengalami proses yang panjang, dahulu komunikasi hanya dilakukan dengan menggunakan isyarat, kemudian berkembang dengan menggunakan bahasa lisan, lalu dikenal komunikasi dengan tulisan dan akhirnya sampailah pada era media massa sederhana dengan berkembangnya tradisi menuliskan pesan atau informasi yang digandakan, kemudian disebarkan kepada khalayak luas. Media massa memungkinkan penyampaian informasi yang sangat cepat dengan khalayak yang sangat luas, berkembangnya media massa menyita perhatian yang cukup besar dari masyarakat, sehingga memungkinkan juga digunakan sebagai media dakwah yang cukup efektif, seperti yang kita liat saat ini perkembangan dakwah melalui televisi, radio, bahkan di media cetak sekalipun. Besarnya peluang untuk berdakwah melalui media massa, sebagai contoh, memunculkan fenomena dakwahtaiment, yaitu dakwah yang dibalut atau dipadukan dengan hiburan bagi masyarakat. Hal ini sematamata dilakukan dengan tujuan menarik perhatian masyarakat muslim, dan metode agar 
pesan-pesan dakwah yang disampaikan dapat diterima dengan mudah oleh berbagai kalangan di masyarakat, karena dakwah yang konvensional yang hanya mengandalkan ceramah di atas mimbar, kadang kurang menarik perhatian sebagian masyarakat utamanya kaum muda.

Seiring kemajuan teknologi komunikasi dan informasi yang berkembang sangat pesat melahirkan perangkat komunikasi yang disebut dengan media baru (smartphone, PDA, laptop, dll), yang merupakan perangkat komunikasi berbasiskan internet, yang memungkinkan melakukan komunikasi lebih mudah, lebih interaktif, dan tidak lagi dibatasi oleh ruang dan waktu. Penggunaan media baru tersebut oleh masyarakat mengakibatkan terjadinya pergeseran pola hidup masyarakat saat ini, khususnya dalam hal berkomunikasi. Perubahan tersebut baik dalam bidang ekonomi, sosial, dan budaya. Salah satu perubahan yang terjadi di masyarakat di bidang ekonomi seperti berkembangnya marketing online atau berniaga melalui internet (e-commerce) yang saat ini populer dengan sebutan onlineshop, hal ini memberikan dampak yang positif yaitu membuka kesempatan yang luas bagi masyarakat untuk berwirausaha dan membuka lapangan pekerjaan yang lebih luas. Akan tetapi perubahan ini dapat saja memiliki beberapa kelemahan, bisa dalam hal berkurangnya omzet bagi pedagang-pedagang di pasar tradisional ataukah berkembangnya perilaku konsumtif di masyarakat. Apabila dipandang dari segi budaya, penggunaan media baru tersebut dapat menggerus budaya dan nilai-nilai lokal yang dimiliki oleh masyarakat karena mudahnya mengakses infomasi yang bermuatan budaya yang bertolak belakang dengan budaya Indonesia. Hal ini dimungkinkan karena mudahnya mengakses informasi setiap saat melalui telepon genggam. Perubahan di bidang sosial khususnya di bidang media massa, yang ditimbulkan oleh kemajuan teknologi komunikasi dan informasi dan munculnya media baru, membuat media massa seperti televisi, radio, dan media cetak lainnya kini menjadi media tradisional. Media tersebut tergeser oleh media online yang menampilkan berita dan informasi yang lebih aktual dan dapat diakses oleh khalayak lebih mudah dan tanpa dibatasi oleh ruang dan waktu. Munculnya media baru tersebut memungkinkan terjadinya 
konvergensi media yaitu dimana satu perusahaan media bisa diakses dengan berbagai jenis media komunikasi, contohnya saja, surat kabar Kompas yang dahulu hanya berupa media cetak yang terbit setiap pagi, kini beritanya dapat juga kita akses melalui internet yaitu www.kompas.com (Arnus,246:2014), dengan adanya konverensi media tersebut dapat memudahkan masyarakat dalam mengakses berita dari suatu perusahaan media massa, dimana masyarakat dapat mengakses berita dengan beberapa cara baik menggunakan media cetak, media audio, media audio visual, dan bahkan sekarang ini melalaui berita online melalui dukungan jaringan internet yang semakin maju.

Apabila ditinjau dari sudut pandang interaksi antarpribadi, munculnya media baru tersebut dapat menjadikan interaksi antar individu lebih mudah, karena kita dapat berkomunikasi dengan siapa saja tanpa adanya batasan geografis, seiring dengan munculnya beberapa media jejaring sosial seperti facebook, BBM, whatsapp, dan beberapa media jejaring sosial lainnya yang sedang menjadi trend komunikasi saat ini.

Fenomena penggunaan media online dalam mengakses berita dan membangun komunikasi interpersonal melalui media jejaring sosial melahirkan suatu konsep baru dalam komunikasi yaitu CMC (computer mediated communications) yang berkembang seiring lahirnya media baru dan pesatnya penggunaan media komunikasi berbasiskan internet. Pada dasarnya pola CMC digunakan untuk komunikasi interpersonal, akan tetapi seiring dengan perkembangan di bidang teknologi komunikasi dan informasi saat ini, membuat batas antara komunikasi interpersonal dan komunikasi massa hampir tidak ada lagi, pesan-pesan yang dahulu bersifat interpersonal dapat diterima oleh khalayak luas dengan adanya media sosial tersebut. Oleh karena itu menarik bagi penulis untuk menerapkan pola CMC dalam bidang dakwah untuk lebih menpermudah aktivitas dakwah dan lebih memperluas khalayak dari dakwah yang disampaikan oleh para da'i. Sebagai seorang yang bergelut dibidang dakwah tentulah kita harus selalu mencari terobsan baru dalam menyampaikan ajaran-ajaran Allah tersebut, salah satunya dengan menggunakan media-media yang berbasiskan teknologi yang sedang populer di masyarakat dengan harapan dapat meraup khalayak yang lebih luas dan pesan-pesan yang 
disampaikan dapat lebih efektif karena dilakukan dengan cara yang sedang banyak disenangi oleh masyarakat.

\section{Pembahasan}

\section{Pengertian Computer Mediated Communication (CMC)}

Computer Mediated Communication atau biasa disingkat dengan CMC dalam Bahasa Indonesia bisa diterjemahkan menjadi komunikasi yang berwahanakan komputer atau komunikasi yang diperantarakan oleh komputer. Kajian tentang CMC ini tergolong baru, mulai berkembang pada tahun 1987. Dalam konteks CMC komputer yang dimaksud tidak hanya perangkat Personal Computer (PC) atau Laptop, tetapi semua alatalat yang berbasiskan komputer seperti PDA, smarphone, tablet, dan sejenisnya, alat-alat tersebut disebut dengan media baru dalam komunikasi.

Computer Mediated Communication (CMC) dapat secara sederhana diartikan sebagai komunikasi yang terjadi antara orang dengan menggunakan media komputer atau melalui komputer (Herring dalam Budiargo, 2015:viii), dan penggunaan teknologi dalam CMC memfasilitasi pertukaran isi semantik melalui jaringan telekomunikasi, yang diproses lewat satu atau lebih komputer antar individu dan antar kelompok (Rice dalam Budiargo, 2015:viii). Maksud dari pola komunikasi ini dapat dicontohkan sebagai berikut, apabila dahulu kita berkomunikasi dengan seseorang atau suatu kelompok hanya mengandalkan komunikasi tatap muka (face to face), dan harus berdekatan secara fisik, sehingga apabila kita ingin berkomuikasi dengan seseorang atau berdiskusi dengan sekelompok orang, maka kita harus bertemu dengan orang tersebut secara langsung, tetapi seiring dengan perkembangan teknologi, muncullah pola CMC yang mendukung munculnya alat-alat komunikasi yang dapat memudahkan kita untuk berkomunikasi satu sama lain tanpa harus bertatap muka atau bertemu secara langsung, atau berdekatan secara fisik. Pola CMC memungkinkan seseorang untuk berkomunikasi dengan menggunakan alat komunikasi yang berbasis komupter, dengan didukung perangkat internet dan aplikasi-aplikasi yang memungkinkan kita untuk membaca berita teraktual 
dari koran online, bisa bermain game virtual yang memungkinkan kita seolah-olah bermain dengan seseorang tetapi orang tersebut tidak berada di dekat kita, kita dapat becakap-cakap, berdiskusi, dengan seseoang dimanapun mereka berada, bahkan trend berniaga saat ini adalah dengan menggunakan media online, dengan adanya media jejaring sosial seperti facebook, twiter, BBM, instagram, dan masih banyak jejaring sosial lainnya.

Cakupan dari CMC itu sendiri termasuk sistem obrolan (chatting), World Wide Web (WWW), termasuk sistem tekstual, grafis, fotografi, audio, dan video disamping aspek-aspek hyperlink, CMC juga mencakup berbagi video seperti Youtube dan sistem jejaring sosial dan sistem pencarian pertemanan seperti facebook dan lain sebagainya.

Pola CMC ini juga dijelaskan oleh Joseph walther dalam teori pemprosesan informasi sosial atau yang lebih sering disingkat dengan SIP (Social Information Procces). Teori pemprosesan informasi sosial menyatakan bahwa di dalam CMC, si pengirim pesan menggambarkan dirinya sendiri dengan cara yang menguntungkan secara sosial dalam rangka menarik perhatian si penerima pesan dan mengembangkan interaksi masa mendatang. Si penerima pesan kemudian cenderung mengidealisasikan citra si pengirim, dan terlalu mengahargai petunjuk berbasis teks yang minimal. Sebagai tambahan, karakter CMC yang asingkronis memberi cukup waktu kepada si pengirim dan si penerima untuk mengedit komunikasi mereka, yang menjadikan interaksi di dalam CMC lebih bisa di kontrol serta mengurangi tekanan pemberian umpan balik yang segera di dalam interaksi face to face (FTF) (http://nindyapoetri.blogspot.com)

Selain teori pemprosesan informasi sosial dikenal juga Model Social Identity Model of Deindividuation Effect (SIDE). Teori ini membebaskan individu dari hambatan-hambatan serta norma-norma sosial dan menghancurkan batasan-batasan sosial. Para pendukung SIDE menyatakan bahwa CMC memperkuat batasan-batasan sosial yang sudah ada. Model SIDE ini menentang pendapat sebelumnya yang mengatakan bahwa kurangnya perilaku normatif, kesopanan, koordinasi, empati, dan keramahan dalam CMC. (http://nindyapoetri.blogspot.com) 
Ada beberapa pendapat mengenai $\mathrm{CMC}$, ada yang mengatakan berkomunikasi dengan CMC kurang memiliki sosioemosional dibandingkan dengan komunikasi face to face akan tetapi menurut Berge (2014:707) semuanya berpulang pada pengguna CMC, setiap pengguna pola ini memiliki tujuan yang berbeda-beda ada yang menggunakannya karena tengah mengupayakan hubungan sosial tetapi ada yang bertujuan untuk meminimalkan keterlibatan dengan orang lain.

\section{Pengaplikasian Pola CMC dalam berdakwah}

Berdasarkan hasil penelitian yang dilakukan oleh penulis yang berkaitan dengan penggunaan pola $\mathrm{CMC}$ yang dilakukan pada mahasiswa IAIN Kendari, didapatkan hasil bahwa sebagian besar informan lebih menyukai melakukan komunikasi dan menceritakan tentang diri mereka atau membuka informasi-informasi tentang diri mereka melalui media jejaring sosial. Bahkan seseorang yang mempunyai sifat introvert sekalipun dapat menjadi sangat terbuka menceritakaan tentang informasi tentang dirinya kepada temantemannya di dunia maya, karena merasa nyaman dalam melakukan komunikasi dengan media yang berbasis internet tersebut. Sebagian besar informan mengatakan bahwa dengan berkomunikasi dengan menggunakan media sosial mereka tidak merasa malu, lebih nyaman untuk mengungkapkan perasaan dan merasa sangat lega setelah menceritakan tentang masalahnya di media sosial dibandingkan dengan berkomunikasi secara langsung atau face to face. Berkomunikasi melalui media sosial juga dapat memberikan solusi terhadap berbagai masalah yang dihadapi oleh para informan, selain itu media sosial juga dapat digunakan sebagai ajang memperluas wawasan mereka dari hasil interaksi mereka dengan teman-teman di dunia virtualnya. Penelitian ini dilakukan kepada responden mahasiswa yang berusia 17-22 tahun, karena berdasarkan hasil survey yang dilakukan terhadap pengguna internet di Indonesia menunjukkan bahwa tingkat pengguna internet khususnya media sosial di Indonesia berada pada usia 17- 25 tahun.

Berdasarkan hasil penelitian tersebut dan melihat trend pengaplikasian pola CMC saat ini di masyarakat, maka penulis ingin mengadopsi konsep tersebut kedalam metode 
untuk berdakwah. Metode dalam berdakwah tentu saja sangat beragam, tidak harus selalu dalam bentuk berkhutbah diatas mimbar, dakwah mempunyai metode yang luas, bervariasi dan fleksibel, oleh karena itu, melihat peluang di era teknologi komunikasi, hal ini dapat menjadi sarana baru dalam mengembangkan dakwah guna menjangkau khalayak yang lebih luas. Perkembangan teknologi tentu saja harus kita manfaatkan sebaik-baiknya untuk kemaslahatan ummat, Hal ini untuk memaksimalkan penggunaan media sosial di internet agar teknologi komunikasi tersebut digunakan tidak hanya sebatas untuk kesenangan semata dan kegiatan yang tidak bermanfaat. Oleh karena itu hal ini menjadi peluang untuk para pendakwah mengekploitasi media ini dalam rangka menyebarluaskan dakwah. Salah satu syarat agar materi-materi dakwah yang dibawakan dapat efektif adalah adanya kenyamanan dalam proses penyampaian dakwah, karena dakwah yang efektif adalah dimana makna dari pesan-pesan yang disampaikan oleh da'i dapat diterima dengan makna yang sama oleh mad'u. Salah satu faktor yang mendukung dakwah yang efektif adalah dengan menggunakan media yang mudah diakses dan pola penyampaian yang disenangi oleh mad'u dalam hal ini dapat terjawab dengan pola CMC ini.

Pengaplikasian pola $\mathrm{CMC}$ dalam berdakwah merupakan pengembangan dari metode dakwah yang telah diterapkan selama ini, yaitu dengan menggunakan media massa maupun komunikasi antarpribadi atau tanya jawab. Bentuk dakwah dengan menggunakan pola CMC yang ditawarkan penulis adalah

\section{Membangun Majelis Virtual}

Gaya hidup masyarakat saat ini yang menggunakan waktu secara efisien, menyukai kepraktisan dan memiliki gaya hidup instan, membuat seorang da'i dituntut untuk selalu mencari metode dakwah yang efektif untuk jamaahnya, seorang da'i tidak ada salahnya untuk mengambil prinsip-prinsip marketing yaitu memberikan pelayanan yang prima kepada pelanggannya dengan cara mengetahui apa saja yang diinginkan oleh pelanggannya, begitu pula bagi seorang da'i sebaiknya selalu mencari metode dakwah yang disenangi oleh jamaahnya agar pesan-pesan yang disampaikan dapat terserap 
dengan baik. Salah satu metode dakwah yang dapat diaplikasikan dengan menggunakan pola CMC ini adalah dengan mengefektifkan media sosial untuk menyebarkan materimateri dakwah.

Media jejaring sosial yang berkembang sangat pesat saat ini menyediakan ruang untuk membangun komunikasi secara interpersonal maupun secara kelompok dengan menyediakan fasilitas kepada penggunanya untuk membangun komunikasi dengan komunitas mereka, hal ini dapat menjadi suatu fasilitas untuk membuat suatu group yang dapat diistilahkan sebagai Majelis Virtual. Suatu wadah untuk berdakwah, memperdalam pengetahuan tentang Islam melalui sharing di media jejaring sosial. Hal ini menjadi salah satu jawaban dari gaya hidup masyarakat saat ini yang telah dijelaskan diatas, sehingga kesibukan yang menyita waktu setiap hari tidaklah menjadi alasan untuk tidak menghadiri suatu majelis dalam usaha untuk memperdalam pengetahuan agama dan mendekatkan diri kepada Allah SWT.

Konsep majelis virtual ini seperti layaknya majelis taklim yang banyak dibentuk dan diikuti oleh masyarakat muslim di Indonesia. Perbedaannya, majelis taklim bertemu secara face to face dan berkumpul pada tempat yang sama sehingga berdektan secara fisik. Anggotanya cenderung homogen, biasanya dibentuk berdasarkan kesamaan lokasi tempat tinggal, pekerjaan yang sama, ataukah berdasarkan suku atau daerah asal, dan lain sebagainya. Sedangkan pada majelis virtual menggunakan fasilitas internet dimana dapat diikuti oleh siapa saja, sehingga cenderung heterogen, dan anonim.

Konsep majelis virtual ini dimana semua komunitas majelis virtual dapat memposting materi-materi yang berhubungan dengan dakwah yang dapat meningkatkan pemahaman anggotanya terhadap ajaran agama, dan meningkatkan ketaatan kepada Allah SWT. Peran seorang da'i adalah untuk mengarahkan anggotanya dan meluruskan pemahaman mereka tentang ajaran Islam, anggota dari majelis ini dapat bertanya, membangi pengetahuan satu dengan yang lainnya ataupun membahas masalah-masalah seputar Agama Islam. Pola CMC menarik karena si pengirim pesan menggambarkan 
dirinya sendiri dengan cara yang menguntungkan secara sosial dalam rangka menarik perhatian si penerima pesan dan mengembangkan interaksi masa mendatang. Pada pola CMC ini memberi cukup waktu kepada si pengirim dan si penerima untuk mengedit komunikasi mereka, yang menjadikan interaksi di dalam CMC lebih bisa dikontrol serta mengurangi tekanan pemberian umpan balik yang sesegera di dalam interaksi face-toface (FTF) sehingga bagi sebagian orang pola ini lebih menyenangkan dan setiap orang dapat memberikan tanggapan dengan mengekspresikan dirinya dalam media tersebut. Dengan demikian, pesan-pesan dakwah yang disampaikan lebih mudah diterima dan dipahami oleh khalayak, serta diaplikasikan dalam kehidupannya. Majelis virtual ini mengadopsi sistem inetraksi pada media jejaring sosial seperti kaskus, facebook, whatsapp, dan media jejaring sosial lainnya yang banyak sekali diminati dan digunakan di masyarakat Indonesia.

Dakwah dengan menggunakan pola CMC memberikan kebebasan dalam memilih pesan-pesan yang diinginkan oleh khalayak, karena khalayak diberikan kesempatan untuk memilih materi-materi dakwah sesuai dengan kebutuhannya.apabila dikaitkan dengan teori komunikasi massa yaitu teori uses and gratifications yang mnyebutkan bahwa khalayak bebas untuk memilih informsi yang diinginkanya dan dibutuhkannya, jadi khalayak hanya akan mengarahkan perhatiannya pada informasi yang mereka butuhkan. bukan informasi yang datang kepada khalayak dan langsung mengena pada diri khalayak seperti pada teori jarum hipodermik, hal ini dipandang lebih efektif dalam menyampaikan pesan-pesan persuasif seperti pada dakwah karena, perhatian khalayak tentuakan terfokus pada hal-hal yang menarik bagi mereka.

\section{Metode Ceramah Online}

Dahulu kita dapat menyaksikan dakwah dari media elektonik seperti TV dan Radio, dengan adanya aplikasi youtube hal ini dapat juga dilakukan, hanya saja dengan menggunakan aplikasi youtube ini seseorang lebih dapat mengatur waktu sesuai dengan keinginan mereka, dapat diulang sesuai dengan keinginan kita. Menonton video melalui 
youtube bukan merupakan hal yang baru lagi, akan tetapi youtube yang menampilkan ceramah agama atau pesan-pesan keagamaan masih belum lazim dilakukan oleh masyarakat saat ini.

Selain tidak terbatas oleh ruang dan waktu dakwah dengan menggunakan pola CMC dibandingkan dengan media massa adalah umpan balik yang diberikan lebih cepat tidak tertunda seperti pada media massa, khalayak dapat mengulang pesan-pesan yang ingin dilihatnya .

Sisi positif yang lain dari pengaplikasian pola CMC adalah dakwah yang lebih bersifat inklusif. Mengapa dakwah dengan pola CMC dikatakan inklusif karena dengan menggunakan CMC batas-batas perbedaan yang dapat membentuk streotype-streotype mereka terhadap suku tertentu hampir tidak ada, karena dalam berinteraksi di media sosial, seseorang bebas untuk membangun identitas mereka sesuai dengan keinginannya, jadi dapat dikatakan bahwa cenderung anonim dan bebas untuk menggunakan avataravatar yang sesuai dengan keinginan mereka dalam menggambarkan diri mereka di dunia maya. Latar belakang budaya maupun status sosial seseorang kurang diperhatikan dalam berinteraksi di media sosial. Orang bebas ingin berinteraksi dengan siapa saja tanpa terkotak-kotakkan dengan status sosial dan paham-paham tertentu seperti yang terjadi pada media massa dan komunikasi tatap muka. Hal ini terjadi pada jurnalisme Islam yang juga sebagai jurnalisme dakwah yang kurang berkembang di masyarakat yang disebabkan oleh faktor terbatasnya modal. Hal ini karena tujuan utama dari pers Islam adalah menyebarkan ajaran Allah, para penerbit dan perangkat redaksi terdiri dari orang-orag yang sepaham, dari suatu organisasi, sehingga terbentuklan sifat ekslusivisme, yang menyebabkan orang-orang dari kalangan luar yang berbeda paham kurang tertarik membaca atau menjadi pelanggan media tersebut. Alasan kedua adalah penampilan media Islam yang kurang menarik dan isi yang terlalu berat untuk dikonsumsi oleh orang awam sehingga segmentasi dari media Islam kebanyakan adalah kaum santri dan aktivis organisasi Islam. 
Tren ceramah online ini nampaknya dinikmati tidak hanya oleh khalayak tetapi juga penceramah. Mereka bias dengan mudah menyebarkan kajian islam, mengajarkan akidah dan tauhid tanpa harus mengeluarkan ongkos lebih misalnya uang transportasi dan akomodasi apabila pergi berceramah ke kota lain.

Setiap hari, situs seperti youtube menyiapkan ratusan penceramah yang bersedia mengunduh sendiri ceramah-ceramahnya. Khalayak juga bias mengakses dengan bebas, kajian atau ceramah apa yang mereka minati tanpa merasa dipaksa.Muhammad Haris menulis dalam sebuah blogspot (communitydevelopment.blogspot.co.id) menyebutkan seorang da'i atau mubaligh juga memerlukan pengetahuan di bidang metodologi. Mereka harus memahami apa yang disukai khalayak agar mereka bias terpapar dengan informasi dari ceramah tersebut. Selain itu bila pola berpikir kita berangkat dari pendekatan sistem, dakwah merupakan suatu sistem dan metodologi mempunyai peranan dan kedudukan yang sejajar dengan unsur-unsur yang lain, sepertitujuan dakwah, sasaran dakwah, subjek dakwah, dan sebagainya.

Ceramah online ini pun bias dikombinasikan dengan metode tanya jawab. Hal ini dimudahkan dengan system live streaming. Para khalayak bias bertanya dengan mengirimkan pesan teks di youtube. Atau jika mereka live streaming menggunakan instagram dan facebook, komentar dan pertanyaan para penonton itu bias muncul pada saat itu juga.

Bahkan, seorang penonton bisa langsung mematikan atau memindahkan kanal youtubenya apabila dia tidak menyukai materi ceramah yang diaksesnya. Bahkan secara bebas, mereka bisa meyatakan ketidaksukaannya pada materi ceramah dan secara bebas menyerang para penceramah secara verbal jika mereka tidak sepakat.

Ruang ini memberikan kebebasan kepada siapa saja karena tidak adanya interaksi tatap muka. Terkadang, keengganan dan sopan santun yang dijaga hanya muncul jika terjadi tatap muka. Tidak adanya batasan-batasan yang mengikat dalam interaksi CMC diperkuat oleh Teoritisi SIDE yang mengungkapkan bahwa Pengguna CMC dalam hal 
perilaku yang impersonal dan sarat permusuhan menjadi lebih baik dijelaskan sebagai cerminan norma kelompok bukannya sebagai reaksi deregulatif terindividuasi: "Anonimitas visual cenderung meningkatkan penonjolan identitas sosial dengan menekankan perbincangan anggota kelompok dan mengaburkan perbedaan antarpribadi (Reicher, dalam Berger 710:2014).

\section{Penutup}

Pengaplikasian pola CMC`dalam berdakwah memiliki banyak keunggulan akan tetapi tentu saja juga memiliki beberapa kelemahan, seperti yang seringkali diperdebatkan oleh para ahli yang mengkaji masalah CMC tersebut, diantaranya kurangnya penggunaan isyarat nonverbal dalam pola tersebut. Apabila berdakwah di depan publik atau secara face to face khalayak dapat melihat penegasan dari pesan-pesan yang disampaikan oleh seorang da'i melalui pesan-pesan nonverbal yang tampak dari gerak tubuh dan apa yang dikenakan oleh sang da'i, tetapi di media online isyarat nonverbal tersebut hampir tidak ada, akan tetapi hal ini tentulah tidak terlalu merisaukan karena teknologi dibidang tersebut berkembang sangat pesat, dengan melahirkan teknologi yang memungkinkan kita dapat melihat wajah lawan komunikasi kita secara langsung, sehingga kita seakan-akan berbicara layaknya berkomunikasi secara face to face.

Kendala lain dari pengaplikasian pola ini sebenarnya bagaikan pisau bermata dua, di lain sisi dapat mempererat hubungan antar manusia akan tetapi dapat pula menjauhkan hubungan hablul minnannas seseorang. Berkembangnya media online memungkinkan seseorang tidak merasa perlu lagi untuk bertemu secara langsung dengan berdekatan fisik, tetapi merasa cukup dengan bertemu di dunia maya saja, padahal manusia diciptakan tetap membutuhkan kedekatan seperti itu, tidak cukup hanya melalui media online saja di dunia maya. Oleh karena itu penulis menganggap bahwa penerapan pola CMC ini sebagai pelengkap dan memperkaya metode dakwah yang telah ada sekarang ini. Metode dakwah yang dilakukan secara face to face hendaknya tidak dihilangkan dan akan terus dikembangkan sehingga tidak kalah dengan kemajuan teknologi saat ini. 
Tetapi apapun dampak yang ditimbulkan dari pola CMC ini kita tidak dapat sama sekali membendung arus perubahan yang ditimbulkan oleh perkembangan teknologi komunikasi yang sangat pesat tersebut, yang dapat kita lakukan adalah menggunakan perkembangan teknologi tersebut untuk kemajuan kita di jalan yang dapat memajukan dakwah dan selalu bersikap bijaksana dalam menyikapi perkembangan tersebut. 


\section{DAFTAR PUSTAKA}

Ardianto, Elvinaro dan Komala, Lukita Erdinaya. 2004. Komunikasi Massa: Suatu Pengantar. Bandung. PT. Remaja Rosdakara.

Arnus, Sri Hadijah. 2014. Industrialisasi Media Massa dan Etika Jurnalistik. Jurnal Al-Munzir. Kendari. FUAD IAIN Kendari.

Berger, Charles R, Roloff, Michael E., dan Ewoldsen, David R.Roskos, Handbook Ilmu Komunikasi, Bandung. Penerbit Nusa Media, 2014.

Budi, Rayudaswati, Pengantar Ilmu Komunikasi. Makassar. Kretakupa Print. 2010

Budiargo, Dian, Berkomunikasi Ala Net Generations, Jakarta, PT. Elex Media Kompetindo, 2015

Budianto, Heri \& Hamid, Farid. Ilmu Komunikasi: Sekarang dan Tantangan Masa Depan. Jakarta.Kencana Prenadamedia Group. 2013

Cangara, Hafied, Pengantar Ilmu Komunikasi. Jakarta. PT.Rajawali Pers, 2002.

Devito, Joseph A. The Interpersonal Communication Book. USA: Pearson Education Inc, 2007.

Iriantara, Yosal, Komunikasi Antarpribadi. Jakarta. Universitas Terbuka, 2008.

Nasution, Zulkaimen, Perkembangan Teknologi Komunikasi. Jakarta. Universitas Terbuka, 2010.

Nurudin, 2008. Sistem Komunikasi Indonesia. Jakarta. PT.RajaGrafindo Persada. , 2008. Komunikasi Massa. Jakarta. PT. RajaGrafindo Persada.

Pamuncak, Dimas, Pengaruh Tipe Kepribadian Terhadap Self Disclosure Pengguna Facebook. Skripsi UIN Syarif Hidayatullah Jakarta, 2011.

Rakhmat, Jalaluddin, Psikologi Komunikasi. Bandung. PT. Remaja Rosdakarya, 2000. Sendjadja. S. Djuarsa, dkk. Teori Komunikasi. Jakarta. Univesitas Terbuka, 1994. 
Severin, J. Werner dan Tankard, W. James. Teori Komunikasi, Sejarah, Metode, dan Terapan di dalam Media Massa, Edisi Kelima. Jakarta. Kencana Prenada Media Group, 2008.

Tubss, Stewart.L, Sylvia Moss, Human Communication. Prinsip-Prinsip Dasar. Bandung. PT. Remaja Rosdakarya, 2008.

Vivian, John.. Teori komunikasi Massa, Edisi Kedelapan. Jakarta. Kencana Prenada Media Group, 2008

\section{MAJALAH DAN INTERNET}

www.ariflukmannadirin@blogspot.com

www.chandraadiputra@ blogspot.com

Nindya kartika putri http://nindyapoetri.blogspot.com/2010/06/internet-sebagaicomputer-mediated.html

https://lumanda.wordpress.com/2010/03/08/profil-kota-kendari/

https://id.wikipedia.org/wiki/Dakwah

http://comunitydevelopment.blogspot.co.id/2011/04/macam-macam-metode-dakwahdan.html

www.kompas.com 